地 37 巻 $\stackrel{\text { 震 }}{\text { 第 } 284 \text { 第 } 2 \text { 輯 }}$

\title{
反射波を用いた京都盆地東南部の 基盤構造の推定
}

\author{
京都大学理学部地球物理学教室 天池文男 \\ 京都大学防災研究所 春日 茂 ${ }^{11}$ \\ 京都大学理学部地球物理学教室 岸本清行 ${ }^{2)}$ - 小林芳正 \\ 京都大学防災研究所 岩田知孝・入倉孝次郎 \\ (昭和 58 年 12 月 12 日受理)
}

\section{Exploration of Base Rock Structure in the Southeastern Kyoto Basin by Means of Reflected Waves}

\section{Fumio AmaIKe}

Department of Geophysics, Faculty of Science, Kyoto University

Shigeru KASUGA

Disaster Prevention Research Institute, Kyoto University

Kiyoyuki Kisımoto and Yoshimasa KobayashI

Department of Geophysics, Faculty of Science, Kyoto University

Tomotaka IwATA and Kojiro IRIKURA

Disaster Prevention Research Institute, Kyoto University

(Received December 12, 1983)

In a southeastern part of Kyoto basin, we observed the reflected waves from the basement some hundred meter deep by using air gun as a source and signal-enhancement technique by stacking. Both the velocity up to and the depth of the basement were greater than those previously given by KITSUNEZAKI et al. (1971). It is useful to use reflected waves for exploring sharp boundary, such as a basement, because it is relatively easy to observe them at far distances where surface waves are not disturbing. Synthetic seismograms also support the prospect to detect reflected phases from a sharp boundary.

\section{§1.はじめに}

地震工学の分野では, 地震基盤面およびそこまでの地下構造の決定が重要である. 近年, 構 造物が長大化するとともに地震工学で扱われる地震動の周期範囲が広がり，それに伴つてより 深い地盤の構成を明らかにする必要性が指摘されている [太田・鏡味 (1976); 小林 (1978)].

昭和 57 年 4 月 10 日発表

1) 現所属：海上保安庁水路部

2) 現所属：通産省工業技術院地質調査所 
また実際に, 比較的深い（数百 $\mathrm{m}$ 数 $\mathrm{km}$ ) 地震基盤面までの速度構造を探る種々の試みが成 されている，そのうち，比較的精度よく構造を推定できるのは実体波を用いる方法で，主に爆 破震源を用いる屈折法とボーリング孔中に受震器を設置して観測する検層による方法とがある. 例えば関東平野では，爆破震源を用いた屈折法 [嶋・他 $(1976 \mathrm{a}, \mathrm{b}, 1978 \mathrm{a}, \mathrm{b}, \mathrm{c})$; 瀬尾・小林 (1980)] や，孔井を利用した検層 [太田・他 $(1977,1978)$; 山水・他 (1981)] が行なわれた結 果, 基盤構造について多くの成果が得られている. 一方, 京都盆地においても基盤構造を探る 試みがいくつか成されてきた[狐崎・他 (1971); 小林・他 (1980); 入倉・他 (1980); AMAIKE et al. (1982)]. 狐崎・他（1971）は爆破震源を用いた屈折法により京都盆地南部の基盤構造を 推定した。 小林・他 (1980) は都市域でも実用可能な震源としてェアガンを採用し, さらに震 源の弱さを補らためにスタッキングによる signal enhancement の技術を使つて，屈折法に より黄檗断層の構造を調査した，入倉・他（1980）は同様の方法を用いて地震基盤面からの反 射 $\mathrm{P}$ 波を検出し，基盤からの全反射またはそれに近い反射の生じるところで反射波が顕著に現 われることを示した.

深層ボーリング孔を利用して地層構成を調べる探査法はすぐれた方法であるが，深層ボーリ ング孔や特殊な観測装置を必要とするためこれを実現することは比較的困難である[太田・他 (1977)]. したがつて，こうした地下構造を探るためには爆破震源を用いる屈折法探査が行なわ れるのが普通である．ところが，こうした爆破実験も今日特に都市域では実施困難になりつつ ある.これに対し, 非爆薬性震源であるエアガン震源は都市域でも使用可能という長所を持つ が，ダイナマイトの爆発に比べて威力が弱いため, やや遠方の記録に対しては S/N の悪い記 録しかとれない。しかしながら記録の再現性が良いため, 同一展開でエアガン発射をくり返し 記録をスタッキングしさえすれば，比較的遠方まで容易に良質の記録を得ることができる。

以上の背景のもとに, 京都盆地東南部地域において, エアガン震源とスタッキングの技術を 用いて基盤からの反射波を観測し，この反射波から従来より詳細な基盤構造を推定したのでそ の結果を述べる．また基盤からの反射波を利用する探査方法のもつ特徵についても考察する.

\section{§2. 観 測}

\section{1. 観測 機 器}

震源にはエアガン (BOLT 600B $\left.20 \mathrm{inch}^{3}\right)$ を用いた。 エアガンの圧力源には窒素を用い， 圧力はほぼ $70 \sim 90 \mathrm{kgW} / \mathrm{cm}^{2}$ で使用した。窒素は初期圧力 $150 \mathrm{kgW} / \mathrm{cm}^{2}$, 容積 $47 l$ の市販 の窒素（ボンベ入り）を利用した。実験は 10 月，11月の夜間に行なわれたが，気温の特に 低い夜には窒素がスムーズに供給されず，しばしば実験を中断しなければならないことがあつ た.これはボンベ中の高圧ガスが短時間のうちに低圧のエアガンに供給されるため, 断熱膨張 によりガスの温度が急激に低下するためらしい。このようなときには温度の上昇を気長に待つ か，ボンベに直接湯をかけて実験を続行した，高圧がスを急速に開放する場合にはしばしばと ーターが用いられるとのことである。なお夏期にこのような理由で実験が中断されたことはな い.

観測計器としては, 速度型換振器 (上下動, 水平動, 固有周波数 $8 \mathrm{~Hz}$ ), 直流増幅器 (手製), ディジタルレューダ (TEAC DR1000, 12 ビット， 16 チャンネル)を用い, 記録は 2 ミリ秒 毎にサンプリングしディジタルデータとして磁気テープに採録した. 


\section{2. 観 測 方法}

観測場所は京都盆地東南部にあり， Fig. 1 に示すように京都大学・宇治構 内を通る東西方向に約 $1.6 \mathrm{~km}$ の長さ の測線を設けた。

震源 $(\times)$ は SP1 SP3 の 3 か所で ある. 大学構内にはエアガン用の 2 つ の震源孔が用意されておう、, SP1, SP2 がその場所である。これらは電柱用縦 穴掘削重機で堀られた円孔中に直径約 $90 \mathrm{~cm}$, 深さ約 $2 \mathrm{~m}$ の既製のコンクリ

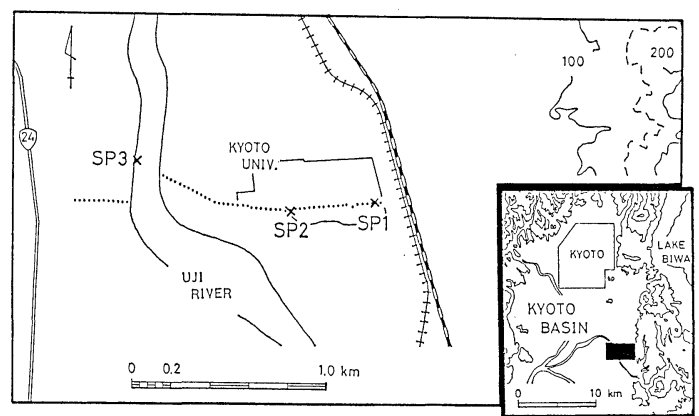

Fig. 1. Location of experiments with shot points $(\times)$ and observation points

ートリングをはめこんだものである。これに水をたたえてェアガンを使用した。 また用いたエ アガンは海洋観測用であるため, 震源孔の内部を砂泥混入防止用のビニールシートで覆つた [安藤・他 (1980) 参照]. な和 SP1, SP2 の震源孔は, 地球潮汐や気圧変化に伴ら地震波速度 変化を検出するために行なわれた安藤・他 (1980), 橋田・他 (1981) の研究の際, 協同で設 けられたものである. SP3 は当地を流れる宇治川を利用しており，小さないかだからェアガ ンをつるして震源とした．震源の深さはいずれも地表（水面）下 $1.0 \sim 1.5 \mathrm{~m}$ である.

Fig. 1 の（）は観測点であり，約 $25 \mathrm{~m}$ おきに 60 か所設置した. 観測においては測線を 5 つに分け，一度に 12 成分の上下動記録， 3 地点で水平動記録 (東西方向), 1 成分の shot mark（上下動，震源から $2 \mathrm{~m}$ 以内に設置）を採録した。むた夜間の観測でもあり，測線の移 動は容易でないため，測線を固定して震源を移動する方式で観測を行なつた．観測は 1981 年 10 月から 11 月の間の数日間をかけて行なつた。測線を宇治川の西にまで設けたのは，後述 するように，理論波形の計算により SP1 からこの距離をで顕著な反射波が期待されたからで ある.

\section{$\S 3$. 観 測 記 録}

得られた原記録は， $\mathrm{S} / \mathrm{N}$ 比を改善するために，10６0 回のスタッキングを行なつた. スタ

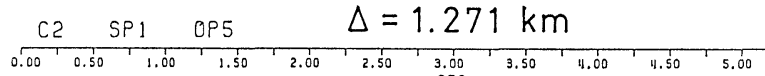

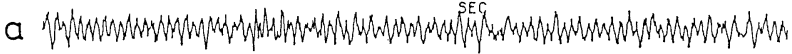

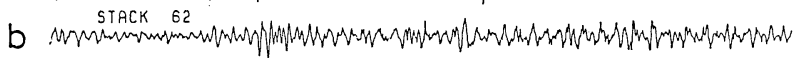

$$
\begin{aligned}
& \text { C MTACK } 51 \text { I } \\
& \text { d } \\
& \text { STACK } 43
\end{aligned}
$$

Fig. 2 Effects of stacking and contamination with traffic noise. (a) Example of an original record for a shot-geophone distance 1,271 meters. (b) Trace 62-times stacked but including traffic noise. (c) Stacked trace from which records contaminated with noisy records due to traffic were excluded, hence only 51-times stacked. (d) Final trace stacked by only 43 severely selected records. 
ッキングの際には，まず shot mark が正常な記録の発震時を読みとり，次に良好な記録を選 び出すという作業を行なつた，良好な記録とは，観測点の近くを走る自動車等による大きな， イズを含まない記録のことである，当実験場は京都市近郊に位置するため，夜間でも自動車通 過によるノイズが避けられないが，記録を選んでからスタックすることにより Fig. 2 のよう に良好な結果が得られる. (a) はスタック前の記録である.これは $\Delta=1.271 \mathrm{~km}$ と比較的遠 方の記録例であるが，信号とノイズの大きさが同程度であるため，観測中は信号の到達をほと んど確認できない（b) は 62 回スタックした記録であるが，自動車のノイズが含まれている ためスタッキングの効果がそれほど上つていない（c）はノイズの大きい記録を除いてスタッ クした例，(d) はさらに記録を厳選して43 回スタックした例である.このよらに固有周波数 $8 \mathrm{~Hz}$ 程度の換振器を用い, 数十回程度のスタッキングしか行なわない場合には, 特に自動車 等による大きなノイズを含む記録を除くことが有効な方法である.

(a)

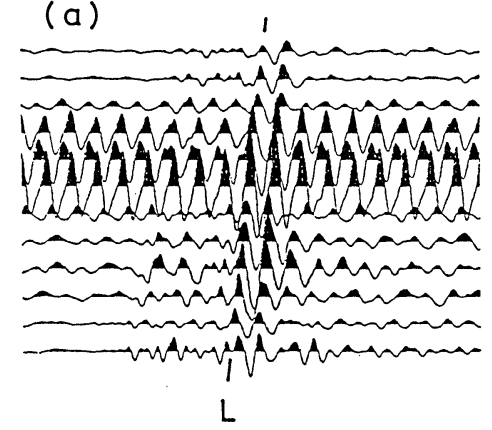

(b)

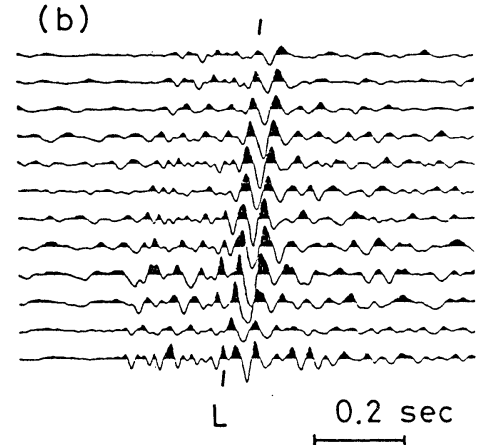

Fig. 3. Effect of Notch filter. (a) Large stationary noises are contaminated in some traces. (b) After being applied digital notch filters $(18 \mathrm{~Hz}$ and $36 \mathrm{~Hz})$ to remove such noises.

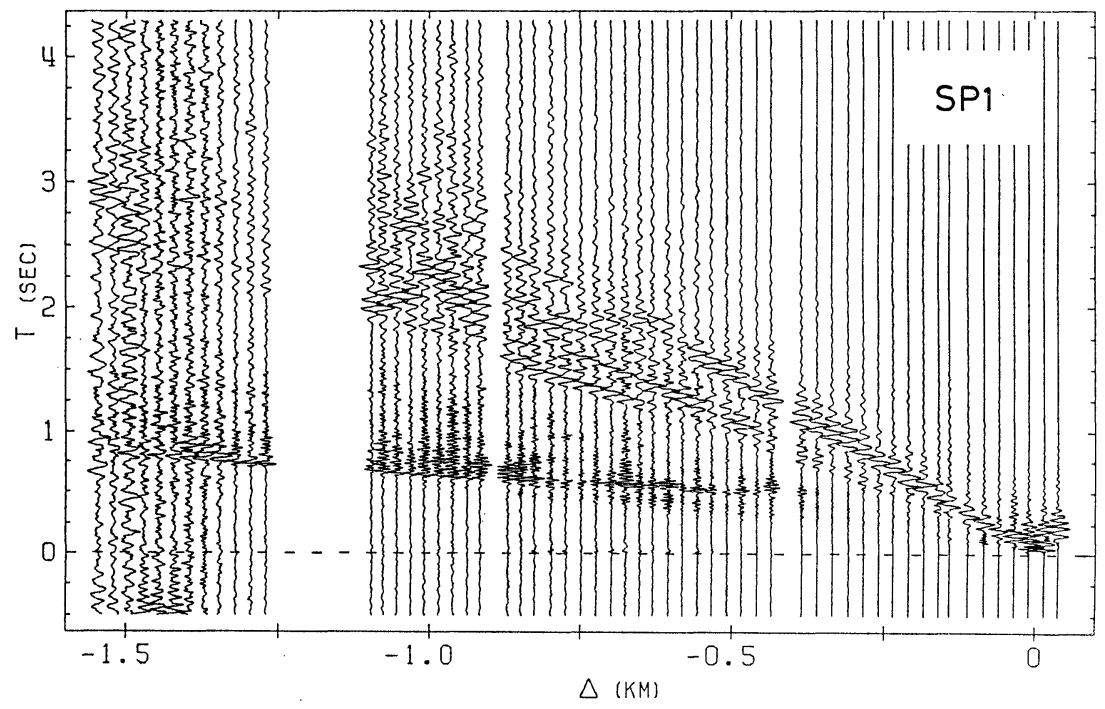

Fig. 4. Paste-up for shots at SP1. 


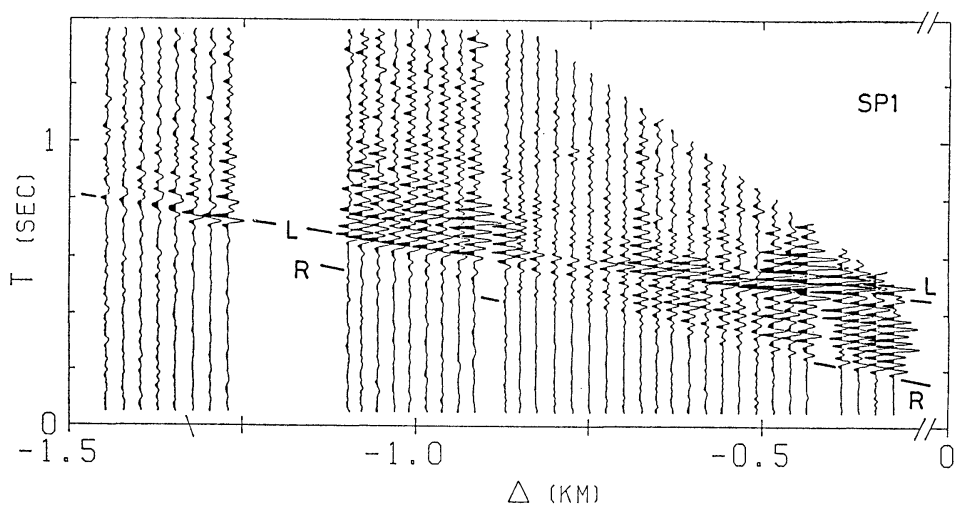

Fig. 5. Paste-up for shots at SP1, enlarged for better recognition of reflection (L) and refraction $(\mathrm{R})$ phases. All traces are on an equal amplitude scale.

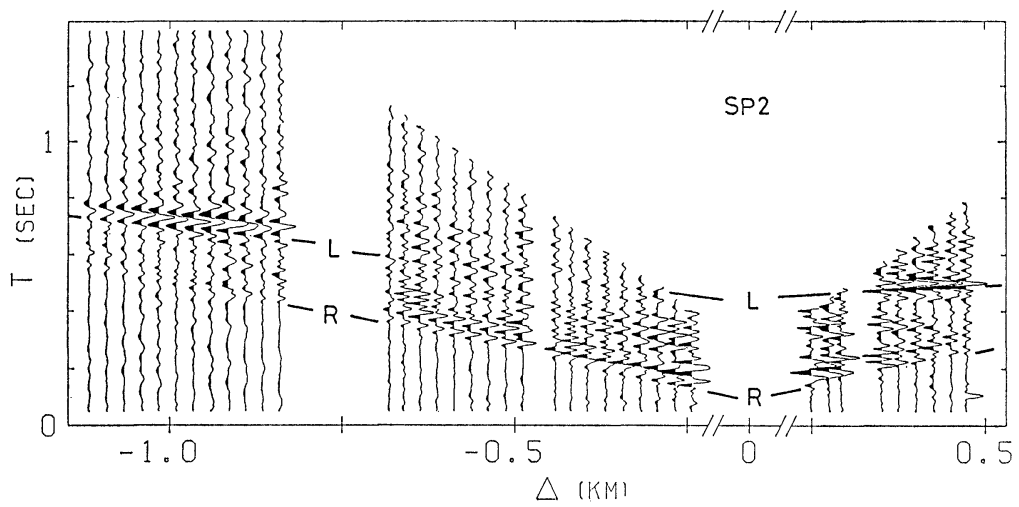

Fig. 6. Paste-up for shots at SP2. All traces are on an equal amplitude scale.

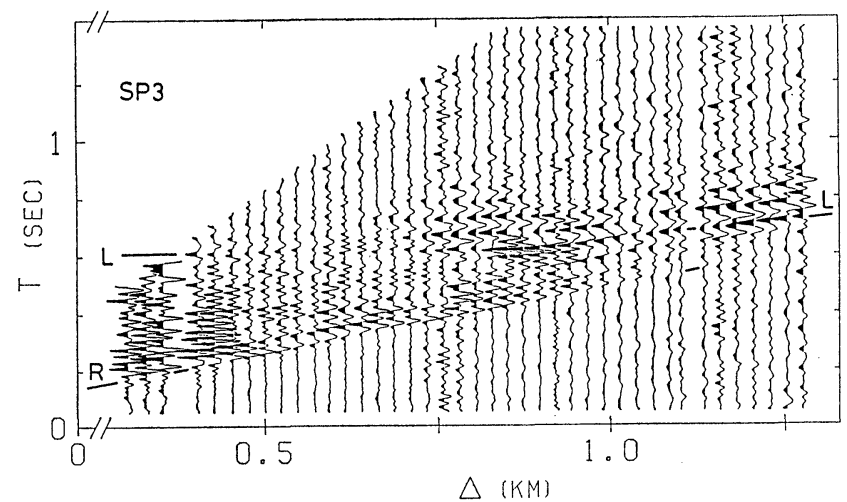

Fig. 7. Paste-up for shots at SP3. All traces are on an equal amplitude scale. 
さらに必要に応じて各種のディジタル・フィルタを用いた，バンドパス，ローパス，ハイパ ス・フィルタの設計は斉藤（1978）によつた。また定常振動を除くためにノッチ・フィルタ [SHANKS (1967)] を用いた。 その適用例を Fig. 3 に示す．（a）には強い定常振動（見かけ周 波数 $18 \mathrm{~Hz}$ ) が含まれているが，この振動は完全な $\sin$ 波形ではない。それはこの定常振動 が高調波を含んでいるためである，そこで $18 \mathrm{~Hz}$ とその倍振動にあたる $36 \mathrm{~Hz}$ のノッチ・フ ィルタをか汁た結果，(b) のようにそれを取り除くことができた。 反射波 (L) は定常振動の 基本振動数と同程度の卓越振動数をもつているが，目で見る限りでは，このフィルタ操作によ って反射波を含む信号成分は大きな影響をらけていないようである。なお，(a)，(b) のいずれ にも $50 \mathrm{~Hz}$ のローパス・フィルタがかけてある. 今回の観測ではこのような定常振動が数か 所の記録に含まれていたため, 同様の処理を行なつた.

以上のような処理を行なつて得られた SP1 の記録が Fig. 4 である. 本論文では，震源名 (SP1, SP2, SP3) を用いて, その震源に対する記録という意味で「SP1の記録」といらょうな 呼び方をする.」は震源からの水平距離であるが，正符号は震源から東方向，負符号は西方向 であることを示している．Fig. 4 では初動が非常に小さくほとんど識別できない， $4 \sim 350 \mathrm{~m}$ 以遠では，初動の後に顕著な反射波が見える．P 波群の後にはより長周期の $\mathrm{S}$ 波群あるいは 表面波が到着するが， $\Delta \sim 1.2 \mathrm{~km}$ 付近にある宇治川を渡るとこの波群の振幅は著しく小さく なつている.

SP1〜SP3 の P 波群部分を拡大した図が Fig. 5 Fig. 7 である. SP1〜SP3 のどの記録 についても初動のみかけ速度は $2.0 \sim 2.2 \mathrm{~km} / \mathrm{s}$ であり，狐崎・他（1971）の言う $2.0 \mathrm{~km} / \mathrm{s}$ 層がこの地域で厚いことがわかる．むたいずれの記録にも，初動である屈折波 (R) の後に顕 著な反射波（L) が存在し，これが基盤上面からの反射波と考えられる.この反射波は 3 つの 記録のらち SP1 で最も顕著である. SP2 の反射波は東側では $500 \mathrm{~m}$ 以内で顕著であるが， 西側ではもう少し遠方の $1 \mathrm{~km}$ 前後で顕著である. SP3 の記録でも特に遠方での反射波が明 瞭である. $\Delta \sim 1 \mathrm{~km}$ 以遠で $\mathrm{S} / \mathrm{N}$ 比がやや劣るのは, 記録のスタック回数が 20 回とやや少な いためである.な和表面波の振幅はたいへん大きいため，Fig. 5 ７ 7゙はそれらをカットして ある。またそれら各図においてはトレース間の相対振幅が保存されている。

\section{§4. 基 盤構 造}

当地の地下構造については既に狐崎・他（1971），狐崎（1970）の結果がある。狐崎・他 (1971) は京都盆地南部で東西方向に約 $11.7 \mathrm{~km}$ の測線を設け， 5 か所の爆破震源を用いた 屈折法により基盤構造を推定した。それによると，本測線下の基盤は泳ぼ水平で約 $370 \mathrm{~m}$ の 深さにあり, 基盤の $\mathrm{P}$ 波速度は $4.4 \mathrm{~km} / \mathrm{s}$ である. また地表から深さ約 $10 \mathrm{~m}$ までは $\mathrm{P}$ 波 速度 $0.9 \mathrm{~km} / \mathrm{s}$ の層があるが，そこから基盤索では $\mathrm{P}$ 波速度 $2 \mathrm{~km} / \mathrm{s}$ の一様な層が存在する とされている.ささらに狐崎 (1970), 狐崎・他 (1971) は, 本測線の東部に位置する京都大学 宇治構内では, 深さ $10 \mathrm{~m}$ 程度までを洪積層のごく上部か沖積層下部とみられる堆積物, そこ から基盤までの $2 \mathrm{~km} / \mathrm{s}$ 層を洪積層，その下の基盤を古生層（または花崗岩層）と想定してい る.

本論文では地表から基盤面をでを一層構造と仮定し，反射波の走時を用いて基盤までの速度 と基盤面を推定する. 最初に基盤面までの平均速度 $\bar{V}_{P}$ を推定する. この平均速度 $\bar{V}_{P}$ は反 
射法で RMS 速度と呼ばれる速度であ る、いま反射面が水平であり，反射面 までの速度が一定とすれば，地表震源 による波の反射波走時 $T$ は, 震央距 離を $X$ として， $T^{2}=a X^{2}+b$ の形の 双曲線になる，ところで反射面の一部 だけが水平であるときには，Fig.8に 示すような共通の反射面をもつ反射波 を用いれば，速度を精度良く求めるこ とができる [DIX (1955)].このように して得られた反射波の走時が Fig. 9 に示されている. 今回のデータで双曲 線で良く近似できるのは，図に示した よらな狭い範囲に限られた。図中の曲 線はこれらの走時を最小二乗法で近似 した双曲線であり，この双曲線のパラ メータから平均速度 $\bar{V}_{P}$ が得られる. ただ反射波は初動でないため，その立 ちあがり時間を正確に決めるのは困難 である.そこで同位相のピークから $\delta t$ 秒前を立ちあがり時間と考えて， $\delta t$ を 0 秒から 0.05 秒 (約 1.5 波長) 変化 させると $\bar{V}_{P}$ はほぼ $2.4 \mathrm{~km} / \mathrm{s}$ から $2.5 \mathrm{~km} / \mathrm{s}$ までの值をとる.

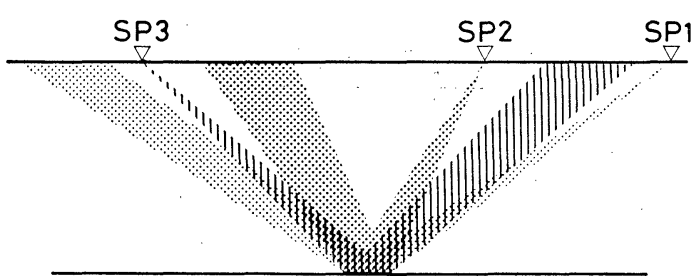

Fig. 8. Reflection phases from common reflection plane are used to determine seismic velocities [DIX (1955)].

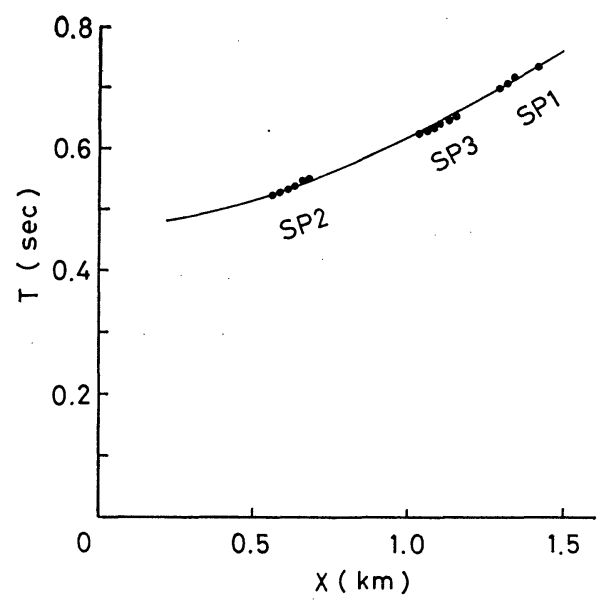

Fig. 9. Observed reflection travel times from common reflection plane (Basement). A best fitted curve is plotted against distance.

次に基盤面を推定する．もし基盤面が傾斜角をもつ平面であると仮定すると，反射波の走時

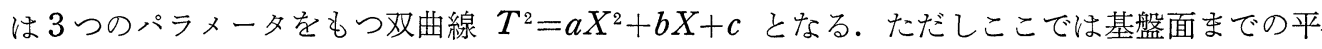
均速度を予め与えるので, 残る 2 つのパラメータから基盤面の傾き $\alpha$ と深さ $\mathrm{H}$ が求められ る. 実際には基盤全体を一つの平面と考えるのは不自然であるため，走時をいくつかに分割し， それぞれを最小二乗法により双曲線で近似する．これらの双曲線から基盤構造を決めることが できる.
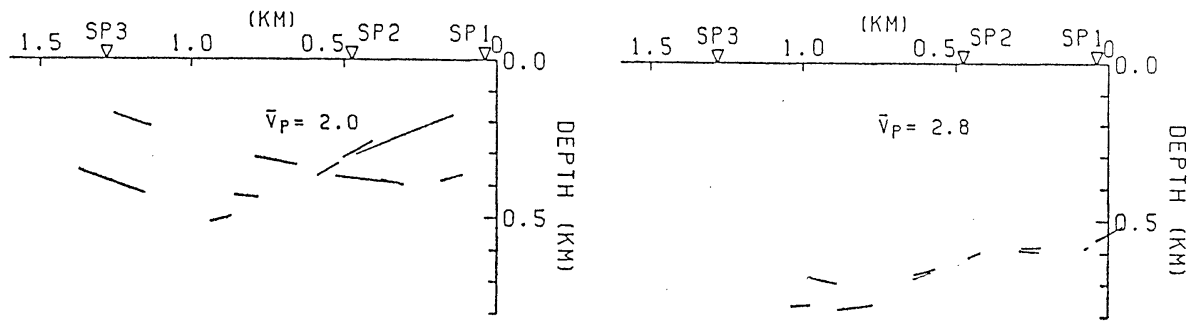

Fig. 10. Estimated basement structures for $\bar{V}_{P}=2.0$ and $2.8 \mathrm{~km} / \mathrm{s}$. Discrepancies in basement depths among spreads are notable. 


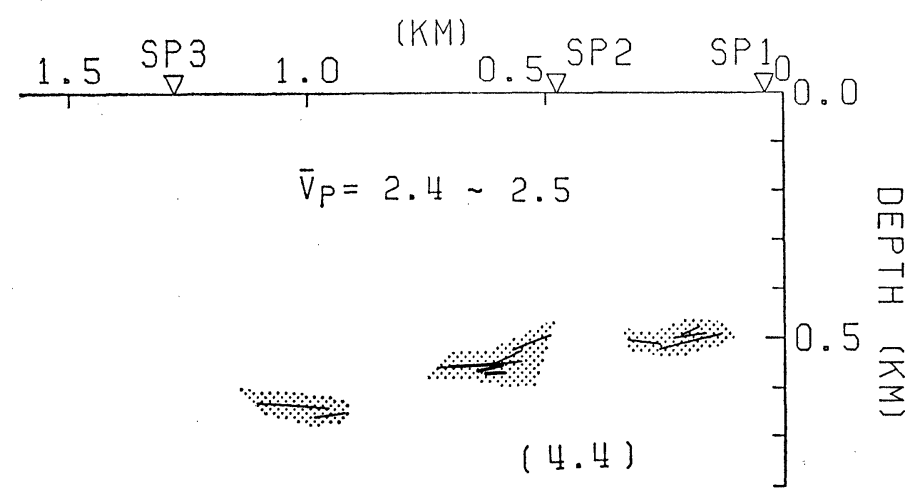

Fig. 11. Estimated basement structure for $\bar{V}_{P}=2.4 \sim 2.5 \mathrm{~km} / \mathrm{s}$. The explanation for dotted area is given in the text.

平均速度 $\bar{V}_{P}$ を与えて構造を決める訳であるが，前に得られた速度を適用する前に， $\bar{V}_{P}$ を $2.0 \mathrm{~km} / \mathrm{s}$ から $2.8 \mathrm{~km} / \mathrm{s}$ まで変えたとき得られる構造を比較してみることにする. まず $\bar{V}_{P}=$ $2.0 \mathrm{~km} / \mathrm{s}$ としたとき得られる構造を検討する，というのは，今回得られた記録の初動の屈折 波走時はいずれも見かけ速度 $2.0 \sim 2.2 \mathrm{~km} / \mathrm{s}$ を示し，また狐崎・他（1971）も基盤までの速 度を $2.0 \mathrm{~km} / \mathrm{s}$ としているからである. Fig. 10 にこのとき得られる構造を示すが，この速度 では構造が全く収束していないことがわかる，他方， $\bar{V}_{P}=2.8 \mathrm{~km} / \mathrm{s}$ としたときにも同様の不 自然さが生じている (Fig. 10)。このように構造を比較検討した結果, $\bar{V}_{P} を 2.4 \sim 2.5 \mathrm{~km} / \mathrm{s}$ としたとき得られる構造が最もまとまりが良くまた無理のない構造になつていると判断できる. これらの結果と Fig. 9 の反射波から得られた結果とを総合して, 我々は $\bar{V}_{P}$ を $2.4 \sim 2.5 \mathrm{~km} / \mathrm{s}$ と結論した。

得られた構造を Fig. 11 に示す. $\bar{V}_{P}=2.45 \mathrm{~km} / \mathrm{s}$ としたとき各走時から得られた境界面が 実線で示されている.Fig. 10 と比べると各境界面が良くまとまっていることがわかる．これ

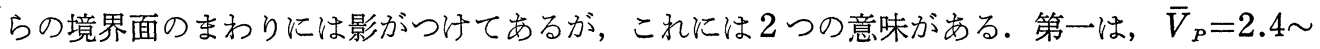
$2.5 \mathrm{~km} / \mathrm{s}$ 変化させたとき, 各境界面がこの範囲内で動くことを示している. 第二は, 反射波 の立ちあがり時間の読みとり誤差による基盤の深さの誤差を示している．この図では反射波の 約半波長にあたる 15 ミリ秒（両側で約 1 波長にあたる 30 ミリ秒）だけ読みとり值を変化さ せたとき変動する範囲を示している.つまり, 平均速度を多少変えたり, 走時を多少読み違え たりすることによつて，上記の方法で得られた構造がどの程度影響を受けるかという目安を与

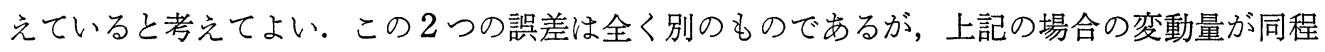
度であるため双方を包含する範囲に影をつけた。 また基盤面を示す実線の内で中央部の太い実 線部分は， $\bar{V}_{P}$ を推定するのに用いた反射波（Fig. 9) がこの部分で反射されたものであるこ とを示している．その際仮定した「水平で共通な反射面からの反射波」といら仮定は，この図 からもほぼ満たされていることがわかる。

Fig. 11 の構造を狐崎・他（1971）の結果と比べてみると，基盤までの速度がやや速くなつ ており，その分だけ基盤面の深さも深くなつていることがわかる．また反射波から得られた今 回の構造では基盤面の微細構造が表現されていると思われる.この点については後で再び検討 する. 


\section{§5. 反射波を用いて基盤構造を探る利点}

ここでは主に理論波形の振幅を用いて基盤のような明瞭な反射面からの反射波を利用する利 点について検討する.

Fig. 12 は平面境界に平面 $\mathrm{P}$ 波が入射したとさの入射角に対する反射 $\mathrm{P}$ 波の反射係数を 示す. 用いた構造は 3 つで諸元は Table 1 に示されている. 3 つのモデルとも下層は一定で あるが，上層の $\mathrm{P}$ 波速度をそれぞれ $2.0,2.4,2.8 \mathrm{~km} / \mathrm{s}$ とし，それに従つて $\mathrm{S}$ 波速度も変 えてある．また上層の密度と厚さは一定としてある.Fig. 12 を見ると，ぞのモデルに対して も臨界角で反射係数が鋭いピークをもち，この臨界角に対応する距離で強い反射波が期待され るように見える.

ところが実際の入射波は平面波でな く球面波であるから，単一の入射角で 振幅を論ずることがでさない。また臨 界角以上の入射角では反射係数の位相 が変化することも考慮しなければなら ない.さらに各観測点への入射角が異 なるため，自由表面の影響も観測点ご とに異なる．したがつてこうした効果 をすべて含さ球状震源に対する実体 波の波形計算を行なつた。計算には

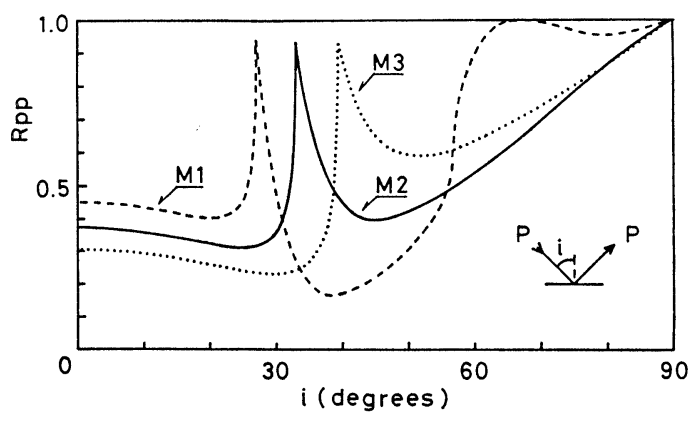

Fig. 12. Reflection coefficients of PP plane waves for three models in Table 1.

Table 1. Three subsurface structures to calculate synthetic seismograms.

\begin{tabular}{cccccc}
\hline \hline $\begin{array}{c}\text { Layer } \\
\text { No. }\end{array}$ & Model & $\begin{array}{c}\text { P wave } \\
\text { Velocity } \\
(\mathrm{km} / \mathrm{s})\end{array}$ & $\begin{array}{c}\text { S wave } \\
\text { Velocity } \\
(\mathrm{km} / \mathrm{s})\end{array}$ & $\begin{array}{c}\text { Density } \\
\left(\mathrm{g} / \mathrm{cm}^{3}\right)\end{array}$ & $\begin{array}{c}\text { Thickness } \\
(\mathrm{km})\end{array}$ \\
\hline \multirow{2}{*}{1} & M & 2.0 & 0.8 & 2.0 & 0.5 \\
\cline { 2 - 6 } & M 2 & 2.4 & 1.0 & 2.0 & 0.5 \\
\hline & M 3 & 2.8 & 1.2 & 2.0 & 0.5 \\
\hline 2 & M 1, M 2, M 3 & 4.4 & 2.4 & 2.4 & $\infty$ \\
\hline
\end{tabular}

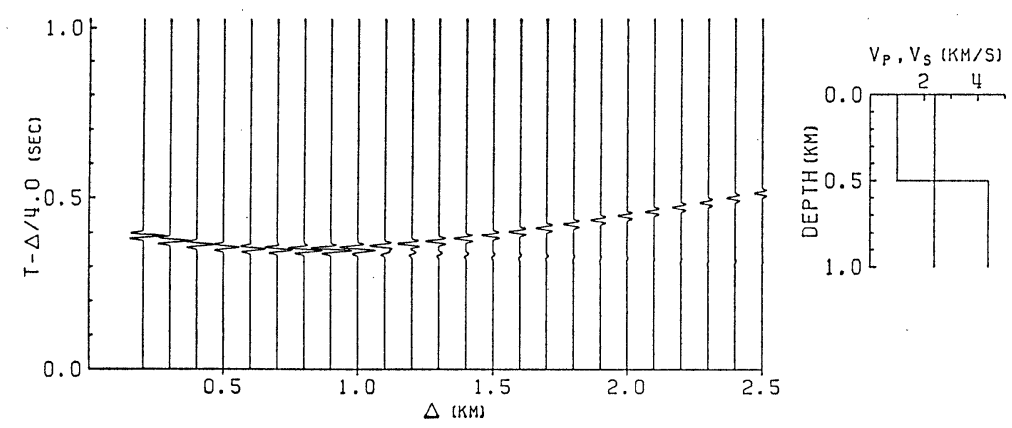

Fig. 13. Synthetic seismograms for model M 2 calculated by Reflectivity Method [FuCHS and MÜLLER (1971)]. The source is an explosion type and only vertical motions of $\mathrm{P}$ wave-group are shown. Effect of absorption is ignored. 


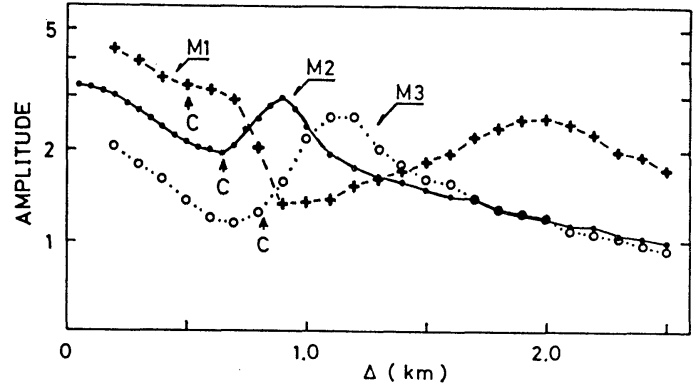

Fig. 14. Amplitudes of reflected waves of synthtic seismograms against distance for three models. Reflected waves have relatively large amplitudes up to large distance.

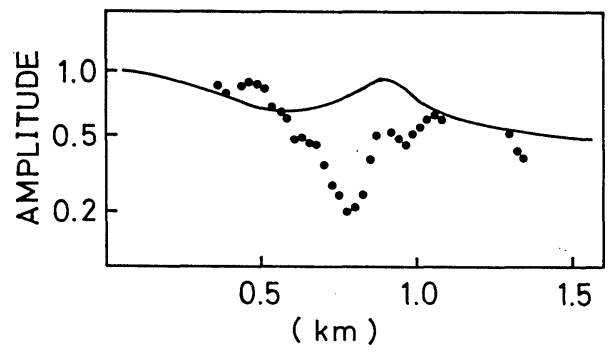

Fig. 15. Observed reflected wave amplitudes for SP1 and calculated amplitude curve for model M 2. Large reflected waves are observed at large distance.
Reflectivtiy Method [FuCHS and MÜLLER (1971)]を用いた。 Q による 減衰の効果は考学ず，P 波部分の上下 動成分の計算を行なつた。また自由表 面による多重反射は計算されていない。 この方法では，計算上ベッセル関数の 漸近展開による近似式 [FUCHS and MÜLLER (1971)] を用いることが多い が，今回のように近距離での波形を計 算する場合にはこの近似は䛊差を生じ るので注意が必要である。このような 場合には，多少計算時間を要するがべ ッセル関数をそのまま計算した。モデ゙ ル M 2 を用いて計算した例を Fig. 13 に示す。これを見ると屈折波と反 射波が観察されるが，屈折波は反射波 に比べると振幅が小さく，乙かも距離 とともに急速に減衰していることがわ かる.この反射波の最大振幅を距離に 対してプロットすると Fig. 14 が得 られる。図中で $\mathrm{c}$ と印した点は臨界角 で反射した反射波の到達距離を示して いる.どのモデルに执いても，反射波 の振幅がピークを持つのは臨界角に対応する距離ではなく，それよりやや遠方においてである. M 2, M 3 では臨界角のピークに対応するピークが見られるものの, M 1 ではピークが形成さ れるに到っていない，これらのモデルでは第一層の厚さは $500 \mathrm{~m}$ と仮定されている．そこで いま参考のため第一層の厚さと等しい距離 $\Delta=500 \mathrm{~m}$ と, $\Delta=2000 \mathrm{~m}$ での反射波の振幅を比 較してみると, どのモデルに対しても，後者は前者の半分以上である. つまり, $2000 \mathrm{~m}$ の距 離で観測される反射波は， $500 \mathrm{~m}$ の距離での反射波の半分以上の振幅を持つと期待できるので ある.今回の観測では宇治川を横断する距離まで測線を長く設定したが，その理由の一つは, 以上のような此較的遠方での反射波の検出を一つの目的としたからである.

基盤からの反射波が比較的広範囲で観測された SP1 の記録について，距離に対する反射波 の振幅をプロットしてみると Fig. 15 が得られる. 反射波の振幅は多少ばらつくため, 隣合 ら 3 点ごとの移動平均を行なつて平滑化してある. 実線は Fig. 11 に示された構造の水平層 モデルである M 2 に対する理論振幅である.こうした単純な水平層モデルの振幅と実際の振 幅とを比較することには疑問が全くない訳ではなく，詳細な議論は避けなければならないが， ここでは以下の 2 点を指摘して打きたいまず反射波が比較的遠方まで大きな振幅を持つこと は，理論波形の計算によつてばかりでなく，実際の観測においても実証できたことである. Fig. 5 7 の記録がこのことを直観的に示している. 次に, Fig. 15 では $\Delta \sim 0.8 \mathrm{~km}$ 付近の 
振幅が理論から予測される振幅に比べて相当小さいことである. 一層構造のモデルを多少変え て波形を計算しても，距離に対するこのように大きな振幅の変化は生じないようである。そこ で考えられる原因として次のことが挙げられる．この反射に対応する SP2 のほぼ真下の基盤 構造を Fig. 11 で見てみると背斜構造をしているょうに見える. そのためにこの部分での反 射波が特に小さくなっている可能性が考兄られる．この立場から見れば，振幅分布も Fig. 11 に示された基盤の微細構造を支持していると言える.

以上見てきたように，反射波は少々遠方でも相当大きな振幅を持つと期待できるようである. 近距離では反射波を乱す大振幅の表面波が存在するが，表面波に乱されない遠方で観測すれば 容易に反射波を観測でさる．基盤のようなコントラストのよい反射面を検出するには，こうし た遠方での反射波を利用する方法が有利であると考えられる.

\section{§6. 結果}

震源にエアガンを採用し，反射波から京都盆地東南部の基盤構造を推定した。 その結果，屈 折法に基づく従来の結果 [狐崎・他 (1971)] に比べて，基盤までの速度と深さはともにより大 きな值が得られた，基盤までの平均速度 $\bar{V}_{P}$ が $2.4 \sim 2.5 \mathrm{~km} / \mathrm{s}$ と屈折波である初動速度 $2.0 \sim$ $2.2 \mathrm{~km} / \mathrm{s}$ に比べて速いことは，基盤までの速度が下部汪ど速くなつていることを示している. この点は今後の研究課題である. な敃堆積地盤中では異方性のため, 沿直方向に伝わる波の速 度は水平方向に伝わる波の速度より小さいとされている [例えば狐崎 (1970); 太田・他 (1977)]. このことは反射波の速度を屈折波の速度より小さくするので，一般に言われている異方性では 上記の現象を説明できない。

本研究では表面波に乱されない遠方での反射波を用いることによつて容易に基盤構造を推定 できることが，理論的にも実験的にも明らかになつた。また震源に非爆薬性震源であるエアガ ンを用いれば都市域でも観測可能であり，さらに記録のスタッキングさえ行なえば相当深部ま での探査を期待できると考兄られる。

\section{謝 辞}

東大海洋研の五十嵐千秋氏には土アガンを预借りした。京大工学部の篠崎祐三氏にはディジ タルレコーダを和借りした。 観測では, 京大理学部学生, 今住 隆氏, 出射隆文氏, 古瀬雅己 氏, 川部喜朗氏, 横井俊明氏, および同大学院生前田憲二氏の補助を得た。記して謝意を表し ます。

なおデータ処理および数值計算には京都大学大型計算機センターの FACOM M 200 および M 382 を用いた。本研究の費用の一部は文部省科学研究費 [自然災害特別研究 (1), 課題番号 00402026, 58020019] によつた.

\section{文献}

Amaike, F., S. Kasuga, K. Kisimoto, T. Iwata, K. Irikura and Y. Kobayashi, 1982, Estimation of Base Rock Structure using Reflected Waves, Proc. 6th Japan Earthq. Engin. Symp., 57-64.

安藤雅孝・須藤 研・橋田俊彦・入倉孝次郎・五十嵐千秋，1980，地震波速度の精密連続観測 (1) 一黄 檗断層付近に抢ける観測一, 地震 2,33, 501-515. 
DIx, C. H., 1955, Seismic Velocities from Surface Measurements, Geophysics, 20, 68-86.

FUCHS, K. and G. MÜLLER, 1971, Computation of Synthetic Seismograms with the Reflectivity Method and Comparison with Observations, Geophys. J. R. astr. Soc., 23, 417-433.

橋田俊彦・安藤雅孝・須藤 研，1981，地震波速度の精密連続観測（2)一屈折波と反射波を用いた観 測一, 地震 $2,34,365-376$.

入倉孝次郎・小林芳正・春日 茂・前田憲二・堀家正則・天池文男・岸本清行，1980，反射波を用い た地震基盤面推定の試み一陸上でのエアガンによる地盤構造探査一, 昭和 55 年度地震学会秋季大 会講演予稿集, 199.

狐崎長琅，1970，京大・宇治構内の地下構造之地震波速度分布，京大防災研究所年報，13A，175-195.

狐崎長琅・後藤典俊・岩崎好規, 1971 , 地震探査から見た京都盆地南部の地下構造とこれに関連した 地震工学上の若干の問題, 京大防災研究所年報, 14A，203-215.

小林啓美, 1978 , 長大構造物の地震動災害と乞の防止に関する研究, 文部省科学研究費自然㷋害特別研 究研究成果 (研究代表者小林啓美), No. A-53-1.

小林芳正・入倉孝次郎・堀家正則・天池文男・岸本清行・春日 茂, 1980 , 黄檗断層の地震探査, 京 大防災研究所年報, 23B, 95-106.

太田 裕・鏡味洋史, 1976 , 耐震工学上考慮すべき地震波の周期の上限と振幅の下限, 建築学会論文 報告, 249, 53-60.

太田 裕・ 後藤典俊 - 塩野計司・高橋 博 - 山水史生・栗原重利, 1977 , やや深い構造の S 波速度一岩 梘 3,500 m 地震観測井での測定とその意義一, 地震 2, 30, 415-433.

太田 裕・後藤典俊・塩野計司・高橋 博・山水史生・栗原重利, 1978, p户深い構造の S 波速度 (II) 一下総 $2,300 \mathrm{~m}$ 地震観測井に和ける測定一, 地震 2, 31, 299-308.

斉藤正徳，1978，漸化式ディジタル・フィルターの自動設計，物理探鉱，31，240-263.

瀬尾和大・小林啓美, 1980 , 人工地震による首都圈南西部の地下深部探査一夢の島-江の島測線の地下 構造一, 地震 $2,33,23-36$.

Shanks, J. L., 1967, Recursion Filters for Digital Processing, Geophysics, 32, 33-51.

嶋 悦三・柳沢馬住 - 工藤一嘉・吉井敏跱 - 一八瀬一郎 - 瀬尾和大 - 山崎謙介 - 大保直人 - 山本喜 俊 - 小口雄康・長能正武, 1976a, 東京の基盤構造. 第 1 回, 第 2 回夢の島爆破実験による地下深 部探查, 地震研究所彙報, 51, 1-11.

嶋 悦三・柳沢馬住・工藤一嘉・瀬尾和大・山崎謙介, 1976b, 東京の基盤構造乞の 2 . 第 3 回夢の島, 吉川町爆破実験による地下深部探査, 地震研究所彙報, 51, 45-61.

嶋 悦三・柳沢馬住・工藤一嘉・吉井敏趟・ 瀬尾和大・黑羽公明, 1978a, 東京の基盤構造その 3. 第 4 回, 第 5 回夢の島爆破実験による地下深部探査, 地震研究所彙報, 53, 305-318.

嶋 悦三・柳沢馬住 - 工藤一嘉・吉井敏赾 - 瀬尾和大 - 大保直人・星野 務・長能正武, $1978 \mathrm{~b}$, 東京 の基盤構造乞の 4. 第 6 回, 第 7 回夢の島爆破実験による地下深部探査, 地震研究所彙報, $\mathbf{5 3}$, $1245-1255$.

沜 悦三・柳沢馬住・座間信作, $1978 \mathrm{c}$, 首都圈の基盤構造, 第 5 回日本地震工学シンポジウム論文集, 321-328.

山水史生・高橋 博 - 後藤典俊・太田 裕, 1981 , やや深い構造の $\mathrm{S}$ 波速度 (III) 一府中 $2,750 \mathrm{~m}$ 観 測井に打ける測定とまとめ一, 地震 $2, \mathbf{3 4}, 465-479$. 